\title{
Hydropeaking effects of on the diet of a Neotropical fish community
}

\author{
Cíntia Veloso Gandini, Francisco Alexandre Costa Sampaioº \\ and Paulo Santos Pompeu ${ }^{3}$
}

The impact of hydropeaking by dams is still poorly understood. Studying the diet of fish subjected to that variation allows us to test the following hypotheses: 1) seasonal and daily changes in river flow, causes changes in the use of the feeding resources; 2) species presenting larger differences in diet between seasons will be those with larger diet changes due to hydropeaking; 3) hydropeaking effects will be more evident in species feeding on items that can be more affected by variable flows. Fish diet collected from the Grande River, downstream from Itutinga Dam, in January and July 2010, was characterized by the feeding index (IA). NMDS, ANOSIM and SIMPER analyses were used to compare the diets under different hydropeaking and season. Relationship among diet dissimilarity between treatments was tested using Pearson Correlation. Seasonality and flow effects were not resulted in changes in the diet of species (hypothesis 1 rejected). In July, there was correlation of differences in the diet between stable and hydropeaking periods with the divergence caused by seasonality (hypothesis 2 accepted). The invertivores guild was the most affected by hydropeaking effects (hypothesis 3 accepted). This is the first study in Brazil that evaluates hydropeaking effects on ichthyofauna.

O impacto da flutuação de vazão causada pelas barragens ainda é pouco entendido. Estudando a dieta dos peixes sujeitos à variação na vazão conseguimos testar as seguintes hipóteses: 1) mudanças sazonais e diárias na vazão do rio promovem mudanças no uso dos recursos alimentares; 2) espécies que apresentam maiores diferenças na dieta entre as estações serão aquelas com maiores mudanças causadas pela variação de vazão; 3 ) os efeitos da flutuação na dieta serão mais evidentes naquelas espécies que se alimentam dos itens potencialmente mais afetados pela variação de vazão. A dieta dos peixes coletados no rio Grande, à jusante da barragem de Itutinga, em janeiro e julho de 2010, foi caracterizada pelo Índice Alimentar (IA). NMDS, SIMPER e ANOSIM foram usados para comparar a dieta em diferentes períodos e estações. As relações entre a dissimilaridade das dietas entre tratamentos foram testadas utilizando Correlação de Pearson. Os efeitos da sazonalidade e flutuação não resultaram em mudanças na dieta das espécies (hipótese 1 rejeitada). Em julho, houve correlação das diferenças nas dietas entre os períodos de vazão estável e flutuante com a dissimilaridade provocada pela sazonalidade (hipótese 2 aceita). A guilda invertívoros foi a mais afetada pelo efeito de flutuação de vazão (hipótese 3 aceita). Este é o primeiro estudo no Brasil que avalia os efeitos da flutuação de vazão sobre a ictiofauna.

Key words: Differences in diet, Flow fluctuation, Rio Grande fish, Invertivorous, Seasonality.

\section{Introduction}

Construction of hydroelectric power plants is among the actions most strongly associated with impacts on aquatic ecosystem (Andrade \& Braga, 2005; Mérona \& Vigouroux, 2006; Agostinho et al., 2008; Postel \& Richter, 2003) and its negative effects downstream from dams are relevant (Agostinho et al., 2008).

Dams affect physical habitat by trapping sediments and nutrients in the reservoir; controlling the flow regime; and changing the connectivity between the river and the floodplain (Poff, 1996; Poff et al., 1997; Agostinho et al., 2008). Flood control can cause great impact in the community, since magnitude, frequency, duration and predictability of the flood pulses are major for regulating ecological processes (Poff et al., 1997; Bunn \& Arthington, 2002).

Information on the fish diet can provide important information about the environment, since it is related to the trophic dynamics of the community and the availability of food resources (Agostinho et al., 2009; Monteiro et al., 2009).

Setor de Ecologia, Departamento de Biologia, Universidade Federal de Lavras. Caixa Postal 3037, $37200-000$ Lavras, MG, Brazil. cgandini@yahoo.com.br(CVG), alexandre.sampaio@rocketmail.com (FACS),pompeu@dbi.ufla.br(PSP) 
Neotropical fish exhibit high trofic plasticity (Abelha et al., 2001; Lowe-McConnel, 1987) and many species change the diet according to the habitat use (Prejs \& Prejs, 1987), which may fluctuate daily or seasonally (Araújo-Lima et al., 1995). For this reason many species feeding generalists, especially when exploiting ephemeral environments (Araújo-Lima et al., 1995).

The main effect of dams on the trophic dynamics is the change of natural flow regime, modifying food resources quality and entry for fish (Abujanra et al., 2009). Some species exhibit opportunistic behavior, replacing scarce food items by another more abundant according to season (Davies et al., 2008).

The fish species of the Grande River change the proportion of the ingested food items seasonally, but keeping food preferences (Gandini et al., 2012). These changes are related to differential abundance of resource (e.g., invertebrates) or differences in the water velocity and turbulence, higher during the wet period, reducing the availability of some fish food on the river bed (Gandini et al., 2012; Tupinambás et al., 2013).

Natural flow regime also increases the heterogeneity of habitats and maintains the richness and complexity of biological communities. However, the flow regime generated to meet energy demands probably does not have the same effects because of the intensity and unpredictability of the artificial phenomenon (Poff et al., 1997). Therefore, it is important evaluate the effects of the new flow regime and how it interacts with fish feeding.

In South America, many studies have evaluated the effects of river regulation by dams on fish communities. Flood control has been associated to fails in recruitment, reduction of migratory fish populations, and impoverishment of the flood plain fish communities (Pompeu \& Godinho, 2006; Gubiani et al., 2007; Suzuki et al., 2008; Gogola et al., 2010). However, daily effects of dams operation have never been addressed for South American rivers.

In order to meet daily variations in energy demand, most hydropower plants increase the amount of electricity generated around $6 \mathrm{pm}$, which increases the amount of water released through the turbines, and decrease again at $10 \mathrm{pm}$; this is called hydropeaking. Studies in several countries indicate that sudden river level variations are responsible for impoverishing aquatic communities in lotic environments downstream from dams. The reasons for these changes are not clearly understood but have been linked to changes in the hydrodynamic habitat (Gore, 1994). Among the changes observed, there are those related to organisms being carried away by the flow; changes in recruitment rate; and nutritional status of some species (Gore, 1977; Corrarino \& Brusven, 1983; Perry \& Perry, 1986; DeJalon et al., 1988).

Using a before-after control-impact experimental design, we studied the diet of fish subjected to daily hydropeaking during the dry and rainy seasons, aiming at testing the following hypotheses: 1) seasonal and daily changes in river flow, causes changes in the use of the feeding resources by the community; 2) species presenting larger differences in diet between seasons will be those with larger diet changes due to hydropeaking; 3) hydropeaking effects will be more evident in species feeding on items that can be more affected by variable flows.

\section{Material and Methods}

The Grande River headwaters are located in the Mantiqueira Mountains and, alongside the Paranaíba River, is one of the main tributaries of the upper Paraná River, which is the second longest river in Latin America (Cemig, 2000). Its drainage area is approximately 143,000 square kilometers (Cemig, 2000) and at least 72 fish species, including rare and endemic ones, can be found (Pompeu et al., 2009). Four important hydroelectric dams are located along the main river channel in the upper Rio Grande basin: Furnas, Funil, Itutinga, and Camargos (Fig. 1). The study area is located approximately $3 \mathrm{~km}$ downstream from Itutinga Reservoir (23K, 535368, 7647367; altitude of $850 \mathrm{~m}$ a.s.l.), comprising rapids and backwater habitats and receiving no contributions from major tributaries (Fig. 1).

During the sampling period, the operation in Itutinga Dam was made to attend the objectives of this study. During 36 days, the river flow rate was maintained near the historical monthly average for the region, $350 \mathrm{~m}^{3} / \mathrm{s}$ and $100 \mathrm{~m}^{3} / \mathrm{s}$ in the months of January and July 2010, respectively. After this, for eight days, hydropeaking were implemented in the river with an increment of $80 \mathrm{~m}^{3} / \mathrm{s}$ from 6 to $10 \mathrm{pm}$. This increment was adopted based on the possible plasticity of the hydropower operation and the historical data of daily fluctuations in the area. Thus, during four hours a day, the river flow rate increased from 350 to $430 \mathrm{~m}^{3} / \mathrm{s}$ in January, and from 100 to 180 $\mathrm{m}^{3} / \mathrm{s}$ in July.

Fish sampling began 30 days after the flow rate modulation started. It was done for six days at constant flow rate, and for eight days at hydropeaking conditions. Therefore, four different sampling were considered: January, with constant flow rate (treatment 1), January, with hydropeaking (treatment 2 ) and the same conditions for the month of July (3 and 4 treatments).

The fish were caught using gill nets and trawls for 14 days in January and July 2010. Two sets of net with mesh sizes between 2.4 and $16 \mathrm{~cm}$ (opposite knots) were used. The gill nets (10 m long and about $1.6 \mathrm{~m}$ high) were inspected every 12 hours, at 6 am and $6 \mathrm{pm}$. The trawls ( $6 \mathrm{~m}$ wide and 1.5 $\mathrm{m}$ high) were used every day at $6 \mathrm{am}, 2 \mathrm{pm}$ and $10 \mathrm{pm}$, always covering the same beach area located on the left bank of the river, in order to keep the same potential assemblage and the available resources.

All fish collected were preserved in 10\% formalin and later preserved in $70 \%$ ethanol and kept in the Ichthyological Collection of the Universidade Federal de Lavras (CI-UFLA $262,264,267,269$ to $273,276,277,280,281,283,287,290$, and 292). Fish caught were separated for dissection and analysis 


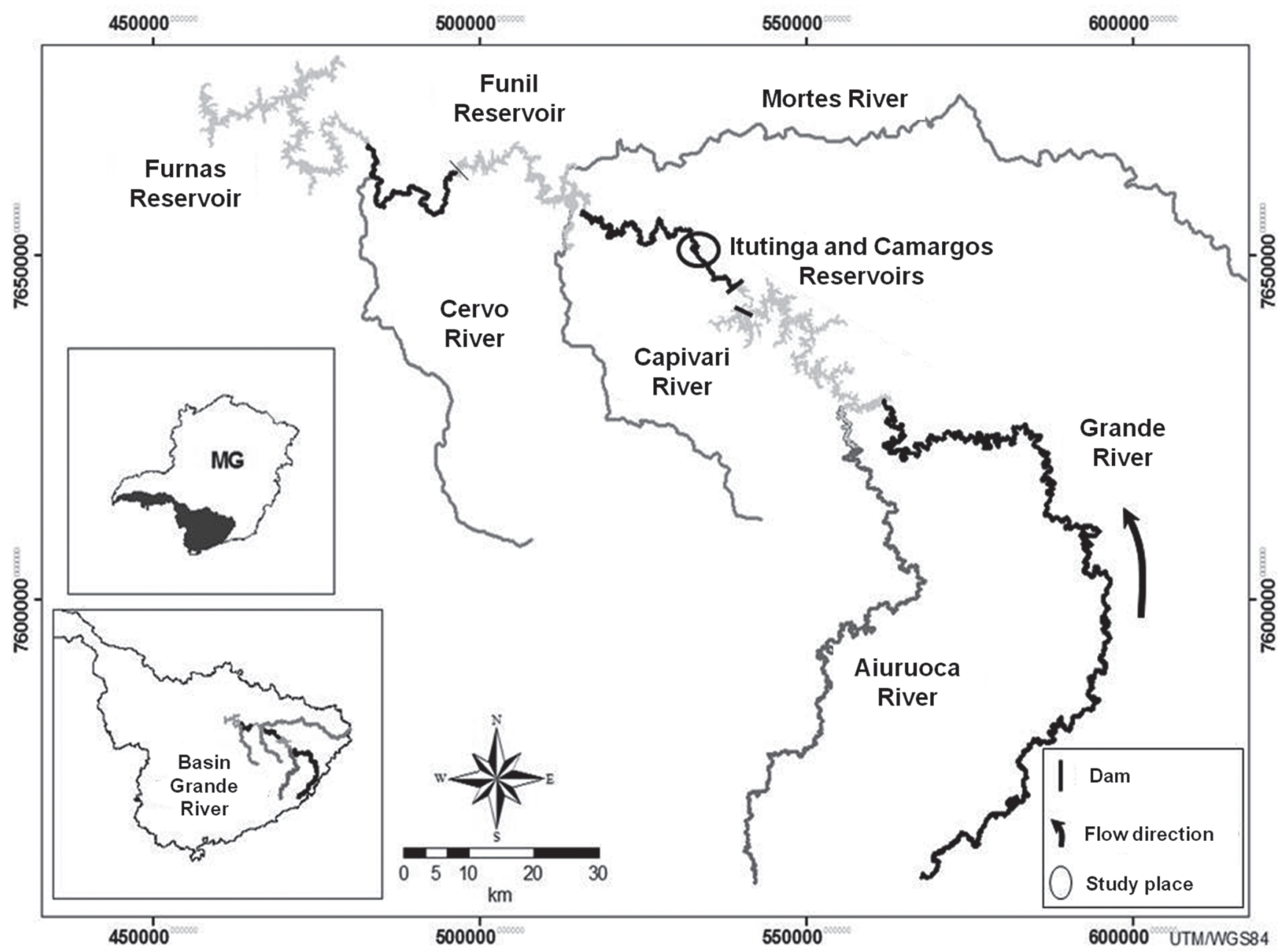

Fig. 1. Schematic drawing of the Grande River basin upstream from Furnas Reservoir. The study area is highlighted by a black circle.

of stomach contents, however for the most abundant species some individuals were randomly chosen. Each stomach was removed through a cut in the abdominal cavity and preserved on alcohol. Food items were identified until minor possible taxonomy category, using stereomicroscope and individually weighed, considering $0.01 \mathrm{~g}$ as minimal weigh. Feeding Index (Kawakami \& Vazzoler, 1980) was used to diet characterization combining the frequency of occurrence ( $\mathrm{F} i=$ the number of times item $i$ appear divided by the total number of stomachs with food) and the relative weight ( $\mathrm{P} i=$ the total weight of item $i$ divided by the total weight of all items) of each item according to the formula:

$$
I A i=\frac{\left(F_{i} \cdot P_{i}\right)}{\sum_{i=1}^{n} F_{i} \cdot P_{i}}
$$

where: $I A_{i}=$ feeding index of item $i ; F_{i}=$ frequency of occurrence of item $i$; and $P_{i}=$ weight of item $i$.

In order to test the first and second hypotheses, the diet of the fish assemblage and from each guild, according to Gandini et al. (2012), was compared among the four treatments (rainy and dry, at constant flow rate and at hydropeaking) using occurrence frequency of items. The multivariate analysis nMDS (nonmetric multidimensional scaling) was used to order the data in the multidimensional space, where distance between species on the matrix is proportional to the similarity. Possible differences among the groups were tested using analysis of similarity (ANOSIM). The contribution of each food item to the observed dissimilarities among the treatments was evaluated using the SIMPER analysis and differences on the consume of each food item were tested among the four treatment using ANOVA (one-way).

The diet dissimilarity (Bray Curtis similarity index) was calculated for each season between stable and hydropeaking conditions, and between seasons considering stable flows. The Bray Curtis index was chosen to incorporate the frequency data, instead of only presence or absence of the item, and because it is considered effective with ecological data (McCune \& Grace, 2002). Relationship among matrices 
obtained by Bray-Curtis distance in January and July were tested using Pearson Correlation (Statistica 8.0).

Differences of invertebrates occurrence based on invertivorous stomach contents (third hypotheses) were evaluated using SIMPER and diferences among the four treatments were tested using (ANOVA one-way).

\section{Results}

A total of 1944 stomachs of 16 fish species belonging to the orders Characiformes, Siluriformes, and Gymnotiformes (Table 1) were analyzed. Seven species were considered herbivores mainly because consumed plant material among which are two of the most common species: Bryconamericus stramineus and Piabina argentea. Further, we found four iliophagous species, three generalists and two invertivores.

It was found a large overlap in the space representing the diet of all species (nMDS) among the fish assemblages in the four treatments studied (Fig. 2: ANOSIM p $>0.05$; Stress $=$ $0.15)$. Sediment, invertebrates, and leaves were the most consumed items, across those treatments (Fig. 3a). Variations were observed in the average frequency of occurrence of items such as plants, invertebrates and sediments due to seasonality and hydropeaking effects, but they were not statistically different among treatments (Figs. 3a-e).

For most of the species, differences in diet among seasons were larger than those promoted by hydropeaking (Fig. 4).

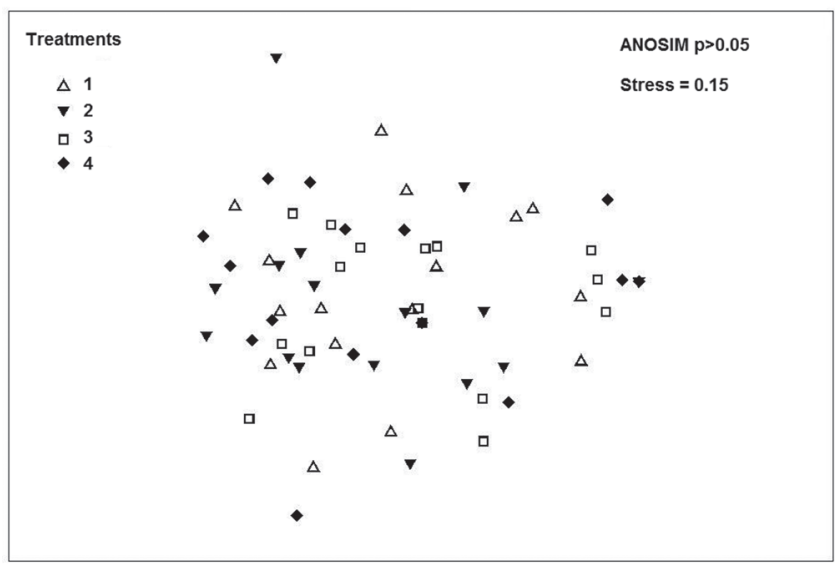

Fig. 2. Results from multivariate analysis nMDS (nonmetric multidimensional scaling) for fish collected in January and July 2010, downstream from Itutinga Dam, Grande River, in the four flow rate treatments ( 1 - constant flow rate in January; 2 - hydropeaking in January; 3 - constant flow rate in July; 4 - hydropeaking in July).

Diet dissimilarity between stable and hydropeaking conditions were correlated to the diet dissimilarity between seasons, only for July (Fig. 4b). In January, the two invertivorous species were the only ones that presented much larger diet dissimilarities between flow treatments, compared to the seasonal diet changes (Fig. 4a).

Table 1. Fish species and number of specimens analyzed per treatments. Trophic guilds were based on Gandini et al. (2012). $\mathrm{N}$ - number of individuals; Treatments: 1 - January stable flow, 2 - January peak flow, 3 - July stable flow, 4 - July peak flow.

\begin{tabular}{|c|c|c|c|c|c|}
\hline Taxon & $\begin{array}{c}\mathrm{N} \\
(1) \\
\end{array}$ & $\begin{array}{c}\mathrm{N} \\
(2) \\
\end{array}$ & $\begin{array}{c}\mathrm{N} \\
\text { (3) } \\
\end{array}$ & $\begin{array}{c}\mathrm{N} \\
(4) \\
\end{array}$ & Trophic guild \\
\hline \multicolumn{6}{|l|}{ Order Characiformes } \\
\hline \multicolumn{6}{|l|}{ Family Anostomidae } \\
\hline Leporinus amblyrhynchus Garavello \& Britski, 1987 & 7 & 1 & 7 & 2 & Invertivores \\
\hline Leporinus elongatus Valenciennes, 1850 & 4 & 11 & 1 & 3 & Generalist \\
\hline Leporinus octofasciatus Steindachner, 1915 & 19 & 26 & 1 & 4 & Herbivores \\
\hline Schizodon nasutus Kner, 1858 & 25 & 16 & 2 & 4 & Herbivores \\
\hline \multicolumn{6}{|l|}{ Family Characidae } \\
\hline Astyanax altiparanae Garutti \& Britski, 2000 & 9 & 5 & 6 & 6 & Herbivores \\
\hline Astyanax fasciatus (Cuvier, 1819) & 24 & 31 & 14 & 18 & Herbivores \\
\hline Bryconamericus stramineus Eigenmann 1908 & 297 & 376 & 52 & 44 & Herbivores \\
\hline Knodus moenkhausii (Eigenmann \& Kennedy, 1903) & 50 & 47 & 82 & 60 & Herbivores \\
\hline Piabina argentea Reinhardt, 1867 & 109 & 132 & 60 & 61 & Herbivores \\
\hline \multicolumn{6}{|l|}{ Family Curimatidae } \\
\hline Cyphocharax nagelii (Steindachner, 1881) & 28 & 20 & 6 & 13 & Iliophagous \\
\hline \multicolumn{6}{|l|}{ Family Parodontidae } \\
\hline Apareiodon affinis (Steindachner, 1879) & 26 & 20 & 25 & 64 & Iliophagous \\
\hline \multicolumn{6}{|l|}{ Order Gymnotiformes } \\
\hline \multicolumn{6}{|l|}{ Family Sternopygidae } \\
\hline Eigenmannia virescens (Valenciennes, 1836) & 2 & 1 & 6 & 1 & Invertivores \\
\hline \multicolumn{6}{|l|}{ Order Siluriformes } \\
\hline \multicolumn{6}{|l|}{ Family Loricariidae } \\
\hline Hypostomus aff. margaritifer (Regan, 1908) & 6 & 3 & 2 & 1 & Iliophagous \\
\hline Hypostomus sp. 1 & 10 & 10 & 7 & 4 & Iliophagous \\
\hline \multicolumn{6}{|l|}{ Family Pimelodidae } \\
\hline Iheringichthys labrosus (Lütken, 1874) & 6 & 5 & 9 & 3 & Generalist \\
\hline Pimelodus maculatus La Cepède, 1803 & 14 & 20 & 8 & 8 & Generalist \\
\hline
\end{tabular}


Considering the invertivorous guild, in January, most of the invertebrate groups found in the stomach contents disappeared after the hydropeaking implementation. In July, changes were mainly quantitative, with an important increase of Ceratopogonidae abundance (Table 2), but they were not statistically different among treatments.

\section{Discussion}

In general, our study found that despite of fairly short, the stretch of the Grande River between Funil and Itutinga power plants retains still several trophic guilds, allowing the maintenance of the stability of trophic interactions (Flecker, 1992; Pimm, 1984). However, most of species does not presented changes in diet when evaluated in different environmental conditions, rejecting the first hypothesis. The comparison of seasonality and hydropeaking effects for the invertivorous species indicated that these species were the most affected by hydropeaking, concluding that the second hypothesis is true. The correlation observed in July allowed to accept the third hypothesis.

Among the seasonal changes generally observed for
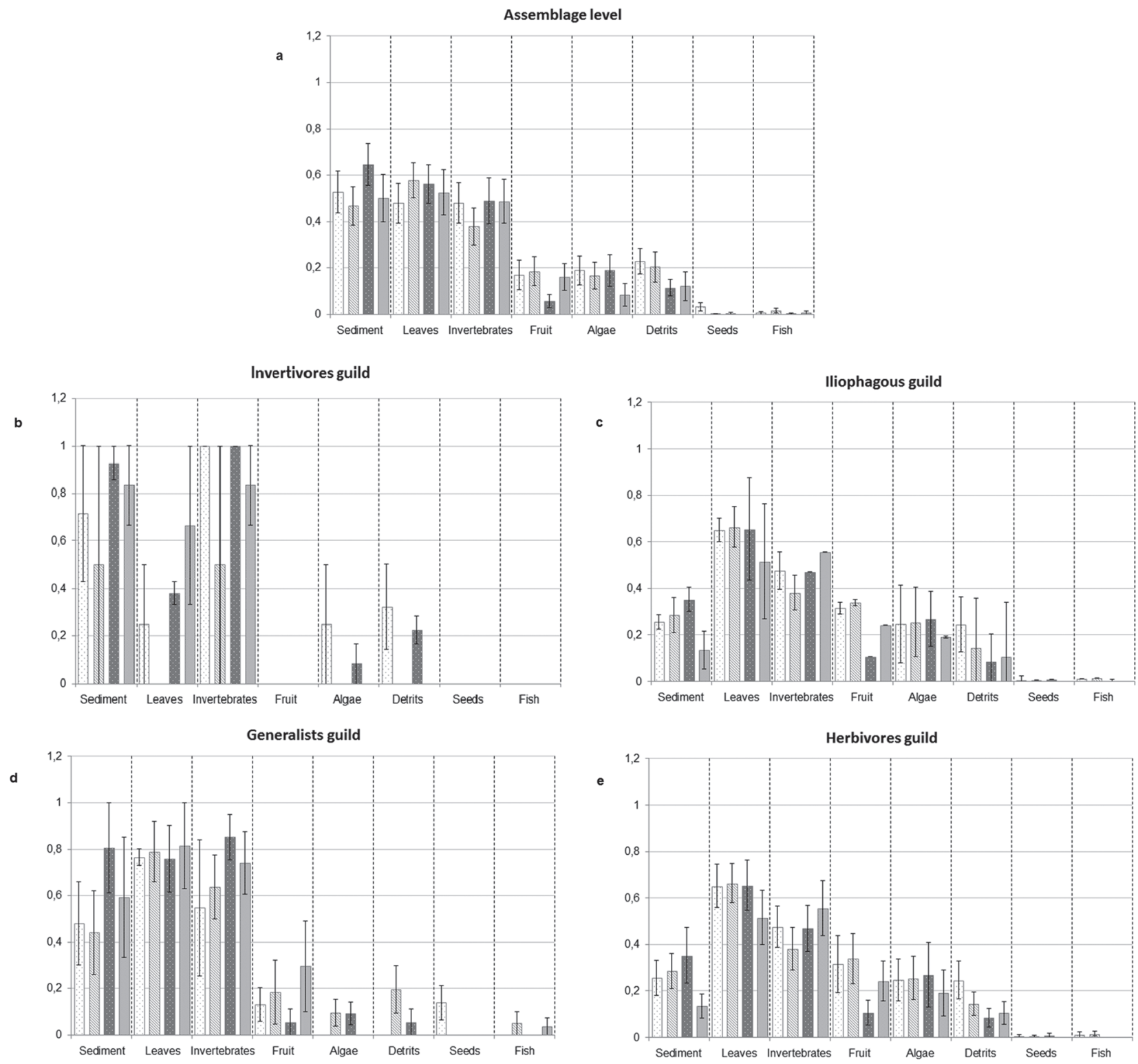

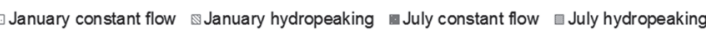

Fig. 3. Average frequency of occurrence of food items in the analyzed treatments based on SIMPER analysis, downstream from Itutinga Dam, Grande River. a - Assemblage level; b - Invertivores guild; c - Iliophagous guild; d - Generalists guild; e Herbivores guild. 

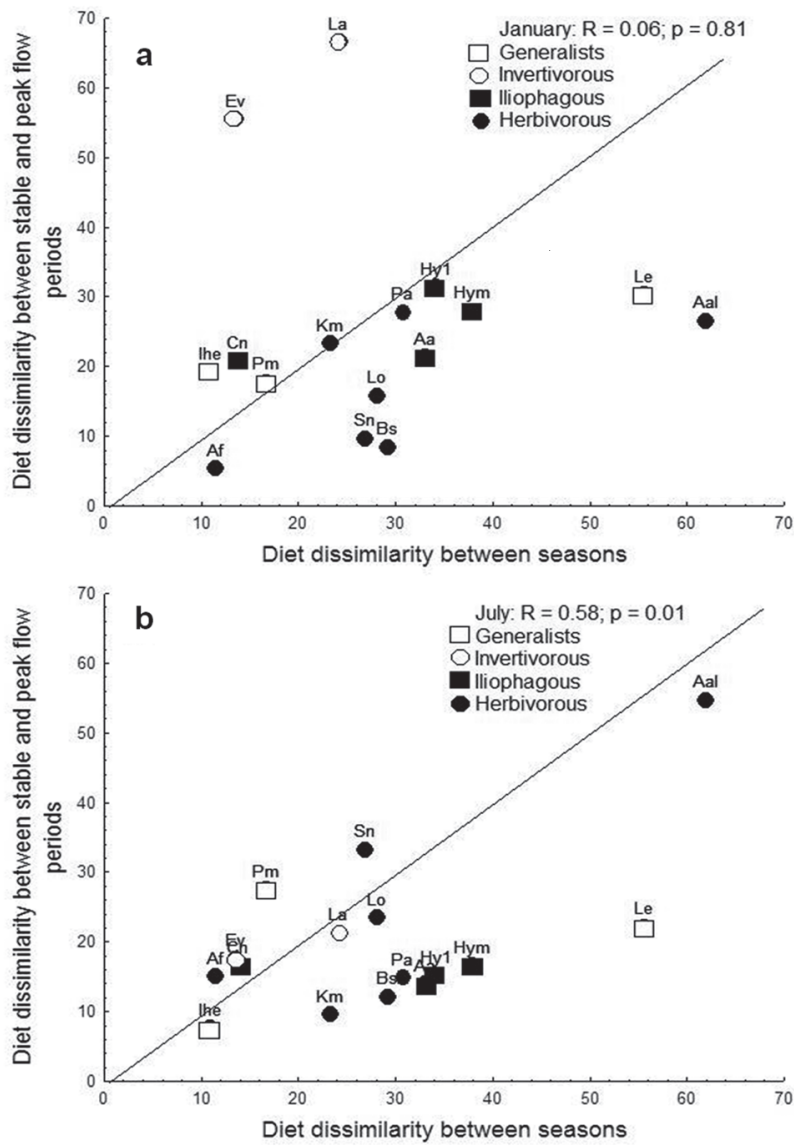

Fig. 4. Relationship among the diet dissimilarity between seasons and diet dissimilarity stable and hydropeaking treatments in January (a) and July (b). Line is representing a linear correlation. Correlation values ( $\mathrm{r}$ and $\mathrm{p}$ ) are indicated. $\mathrm{Aa}=$ Apareiodon affinis; $\mathrm{Aal}=$ Astyanax altiparanae; $\mathrm{Af}=$ Astyanax fasciatus; $\mathrm{Bs}=$ Bryconamericus stramineus; $\mathrm{Cn}=$ Cyphocharax nagelii; $\mathrm{Ev}=$ Eigenmmania virescens; $\mathrm{Hy} 1=$ Hypostomus sp.1; Hym= Hypostomus aff. margaritifer; Ihe= Iheringichthys labrosus; $\mathrm{Km}=$ Knodus moenkhausii; $\mathrm{La}=$ Leporinus amblyrhynchus; $\mathrm{Lo}=$ Leporinus octofasciatus; $\mathrm{Pa}=$ Piabina argentea; $\mathrm{Pm}=$ Pimelodus maculatus; $\mathrm{Sn}=$ Schizodon nasutus.

tropical fish, differences in the abundance of food between the dry and rainy seasons directly affect these communities. In response to these variations, most species are opportunistic (Lowe-McConnell, 1975; Welcomme, 1985; Nico \& Taphorn, 1988). Except for fish with specialized feeding habits (Hahn \& Fugi, 2007), in general, freshwater fish have a wide range of feeding strategies and can adapt quickly to changes in the environment. Therefore, changes in resource availability due to seasonality and changes in nutritional requirements during reproductive period can alter the consumption frequency of items (God \& Petrere Jr., 2003; Hershey et al., 2007; Gandini et al., 2012).

However, this research indicated that despite of the
Table 2. Average frequency of occurrence of invertebrate groups among the stomach contents in the four treatments for the invertivorous species, based on SIMPER analysis. Treatments: 1 - constant flow rate in January; 2 - hydropeaking in January; 3 - constant flow rate in July; 4 - hydropeaking in July.

\begin{tabular}{lcccc}
\hline Item & $\begin{array}{c}\text { Average } \\
\text { frequency (1) }\end{array}$ & $\begin{array}{c}\text { Average } \\
\text { frequency (2) }\end{array}$ & $\begin{array}{c}\text { Average } \\
\text { frequency (3) }\end{array}$ & $\begin{array}{c}\text { Average } \\
\text { frequency (4) }\end{array}$ \\
\hline Chironomidae & 0.722 & 0.5 & 0.928 & 0.666 \\
Diptera (larvae) & 0.361 & 0 & 0.643 & 0.666 \\
Trichoptera (larva) & 0.834 & 0.5 & 0.773 & 0.334 \\
Acari & 0.5 & 0 & 0.416 & 0.5 \\
Simullidae & 0.305 & 0 & 0.405 & 0 \\
Ephemeroptera & 0.25 & 0 & 0.369 & 0.334 \\
Ceratopogonidae & 0.25 & 0 & 0.238 & 0.666 \\
Trichoptera (adult) & 0 & 0 & 0 & 0.167 \\
Diptera (adult) & 0.25 & 0 & 0 & 0 \\
Coleoptera (larva) & 0.0555 & 0 & 0 & 0 \\
Araneae & 0.0555 & 0 & 0 & 0 \\
Mollusca & 0 & 0 & 0.0715 & 0 \\
\hline
\end{tabular}

seasonality and hydropeaking effects, the community remained feeding by the same resource group. Even when evaluated each guild separately, was not possible to observe significant changes on the food resource use, refuting the first hypothesis.

Besides of the availability of resources, the morphology of species is one of the major factors that interfere on feeding spectrum (Gelwick \& Matthews, 2006). Despite of potencial flexibilty of feeding (Lowe-McConnel, 1987) the mouth size and shape body can be limiting diet changes, either by the inability to intake as the low competitiveness with other species in the food search (Gelwick \& Matthews, 2006; Cunico \& Agostinho, 2006). This may also explain the maintaining of species on the same trophic guilds even under different environmental conditions (four treatments). The morphological limitation can be associated with the larger differences in variability of consumed items between seasons among those species with larger diet changes due to hydropeaking, at least in July (second hypotheses).

In the Grande River, benthic macroinvertebrates richness and diversity are larger in wet season (Tupinambás et al., 2013) and change considerably when flows are manipulated (Tupinambás, 2013). In January, the greater variation on frequency of items consumption due to dam operation was observed for the invertivorous species Leporinus amblyrhynchus and Eigenmmania virescens. Beyond the opportunistic behavior of these species, of the promoted flow dynamics on their prey, since negative effects of reservoir manipulations on benthic macroinvertebrates communities have been described (Gore, 1977; McEwen \& Butler, 2008).

There are many ways to assess flow regime requirements for rivers (O'Keeffe et al., 2002), which could be based on hydrologic approaches, hydraulic rating methods, habitat simulation, or holistic methods. Environmental flow rates, if associated with biotic data, can reduce the impacts of 
hydroelectric dams by regulating water flow rate to meet the needs of as many species as possible (Collischonn et al., 2006). Fish diet has been considered an important tool to understand the main effects of dams on watercourses (Merona \& Vigouroux, 2006; Hahn \& Fugi, 2007).

Although the present research was limited to one hydrological cycle and a short strecht of river, was observed that the ability of species to change the feeding is restrict, and invertivorous species are potentially the most affected by hydropeaking. These are the first information on the effects of hydropeaking on fish, based on programmed flow simulations in Brazil, wich can stimulate other related research aimed at better comparison of the impacts of hydroelectric generation in aquatic environments.

\section{Acknowledgments}

The authors thank Companhia Energética de Minas Gerais (CEMIG) / Agência Nacional de Energia Elétrica (ANEEL) for the research fundings; researchers from the Laboratory of Benthic Macroinvertebrates at the Universidade Federal de Minas Gerais for their help in identifying the stomach contents; the biologist Ludmilla Zambaldi (Universidade Federal de Lavras - UFLA) for making the map of the basin; and colleagues from the Laboratory of Ecology of Fish (Universidade Federal de Lavras - UFLA) for their help in collecting material. PSP was awarded a productivity in research grant by $\mathrm{CNPq}$ - Conselho Nacional de Desenvolvimento e Pesquisa (CNPq No. 306325/2011-0) and a Minas Gerais State Researcher Grant by Fundação de Amparo à Pesquisa do Estado de Minas Gerais (FAPEMIG PPM-00237/13).

\section{Literature Cited}

Abelha, M. C. F., A. A. Agostinho \& E. Goulart. 2001. Plasticidade trófica em peixes de água doce. Acta Scientiarium, 23: 425434.

Abujanra, F., A. A. Agostinho \& N. S. Hahn. 2009. Effects of the flood regime on the body condition of fish of different trophic guilds in the Upper Paraná River floodplain, Brazil. Brazilian Journal of Biology, 69: 469-479.

Agostinho, A. A., F. M. Pelicice \& L. C. Gomes. 2008. Dams and the fish fauna of the Neotropical region: impacts and management related to diversity and fisheries. Brazilian Journal of Biology, 68: 1119-1132.

Agostinho, C. A., F. M. Pelicice \& E. E. Marques. 2009. Reservatório de peixe angical: bases ecológicas para o manejo da ictiofauna. São Carlos, RiMa Editora.

Andrade, P. M. \& F. M. S. Braga. 2005. Diet and feeding of fish from Grande River, located below the Volta Grande reservoir, MG-SP. Brazilian Journal of Biology, 65: 377-385.

Araújo-Lima, C. A. R. M., A. A. Agostinho \& N. N. Fabré. 1995. Trophic aspects of fish communities in Brazilian Rivers and Reservoirs. Pp.105-136. In: Tundisi, J. G., J. C. E. M. Bicudo \& T. Matsumura-Tundisi (Eds.). Limnology in Brazil. Rio de Janeiro, ABC/SBL.
Bunn, S. E. \& A. H. Arthington. 2002. Basic principles and ecological consequences of altered flow regimes for aquatic biodiversity. Environmental Management, 30: 492-507.

Cemig. 2000. Guia Ilustrado da Bacia do Rio Grande. CEMIG/ CETEC, Belo Horizonte.

Collischonn, W. C. F. Souza, G. R. Priante, G. K. Freitas, R. Tassi \& S. G. Agra. 2006. Da vazão ecológica ao hidrograma ecológico. In VIII Congresso da Água, Figueira da Foz. Água, sede de sustentabilidade.

Corrarino, A. C. \& M. A. Brusven. 1983. The Effects of Reduced Stream Discharge on Insect Drift and Stranding of near Shore Insects. Freshwater Invertebrate Biology, 2: 88-98.

Cunico, A. M. \& A. A. Agostinho. 2006. Morphological Patterns of Fish and Their Relationships with Reservoirs Hydrodynamics. Brazilian Archives of Biology and Technology, 49: 125-134

Davies, P. M., S. E. Bunn \& S. K. Hamilton. 2008. Primary Production in Tropical Streams and Rivers. Pp. 23-42. In: Dudgeon, D. (Ed.). Tropical Stream Ecology. Oxford, Elsevier.

DeJalon, D. G., C. Montes, E. Barcelo, C. Casado \& F. Menes. 1988. Effects of hydroelectric scheme on fluvial ecosystems within the Spanish Pyrenees. Regulated Rivers, 2: 479-491.

Flecker, A. S. 1992. Fish trophic guilds and the structure of a tropical stream: weak direct vs. strong indirect effects. Ecology, 73: 927-940.

Gandini, C. V., Boratto, I. A., D. C. Fagundes \& P. S. Pompeu. 2012. Estudo da alimentação dos peixes no rio Grande à jusante da usina hidrelétrica de Itutinga, Minas Gerais, Brasil. Iheringia, Série Zoologia, 102: 56-61.

Gelwick, F. P. \& W. J. Matthews. 2006. Trophic Relations of Stream Fishes. Pp. 611-635. In: Hauer, F. R. \& G. A. Lamberti (Eds.). Methods in Stream Ecology. Oxford, Elsevier.

Gogola, T. M., V. S. Daga, P. R. L. Silva, P. V. Sanches, E. A. Gubiani, G. Baumgartner \& R. L. Delariva. 2010. Spatial and temporal distribution patterns of ichthyoplankton in a region affected by water regulation by dams. Neotropical Ichthyology, 8: 341-349.

Gore, J. A. 1977. Reservoir manipulations and benthic macroinvertebrates in a prairie river. Hydrobiologia, 55: 113-123.

Gore, J. A. 1994. Hydrological change. Pp. 33-54. In: Callow, P. \& G. E. Petts (Eds.). The rivers handbook. Hydrological and ecological principles. Massachusetts, Blackwell Science.

Gubiani, E. A., L. C. Gomes, A. A. Agostinho \& E. K. Okada. 2007. Persistence of fish population in the upper Paraná River: effects of water regulation by dams. Ecology of freshwater fish, 16: 191:197.

Hahn, N. S. \& R. Fugi. 2007. Alimentação de peixes em reservatórios brasileiros: alterações e conseqüências nos estágios iniciais do represamento. Oecologia Brasiliensis, 11: 469-480.

Hershey, A. E., K. Fortino, B. J. Peterson \& A. J. Ulseth. 2007. Stream food webs. Pp. 637-659. In: Hauer, F. R. \& G. A. Lamberti (Eds.). Methods in Stream Ecology. Oxford, Elsevier.

Kawakami, E. \& G. Vazzoler. 1980. Método gráfico e estimativa de Índice Alimentar aplicado no estudo de alimentação de peixes. Boletim Institute of Oceanography, 29: 205-207.

Lowe-McConnell, R. H. 1975. Fish communities in tropical freshwaters. Their distribution, ecology and evolution. New York, Longman.

Lowe-McConnell, R. H. 1987. Ecological studies in tropical fish communities. New York: Cambridge University Press.

McCune, B. \& J. B. Grace. 2002. Analysis of Ecological communities. MJM Software Design. Gleneden Beach. 
McEwen, D. C. \& M. G. Butler. 2008. Impacts from water level regulation on benthic macroinvertebrate community structure in Namakan reservoir and rainy lake of Voyageurs National Park, Minnesota. Natural Resource Technical Report. Colorado, Fort Collins.

Mérona, B. de \& R. Vigouroux. 2006. Diet changes in fish species from a large reservoir in South America and their impact on the trophic structure of fish assemblages (Petit-Saut Dam, French Guiana). Annales de Limnologie -International Journal of Limnology, 42: 53-61.

Monteiro, A. de S., A. H. M. Oliveira, F. M. Pelicice \& R. J. Oliveira 2009. Alterações na disponibilidade de recursos alimentares na dieta das principais espécies de peixes. Pp. 77-86. In: Agostinho, C. A., F. M. Pelicice \& E. E. Marques (Eds.). Reservatório de peixe angical: bases ecológicas para o manejo da ictiofauna. São Carlos, RiMa.

Nico, L. G. \& D. C. Taphorn. 1988. Food habits of piranhas in the low llanos of Venezuela. Biotropica, 20: 311-321.

O'Keeffe, J. H. O, D. Hughes \& R. Tharme. 2002. Linking ecological responses to altered flows, for the use in environmental flow assessments: the Flow StressorResponse method. Verhandlungen der Internationalen Vereinigung für Theoretische und Angewandte Limnologie, 28: 1-9.

Perry, S. A. \& W. B. Perry. 1986. Effects of experimental flow regulation on invertebrate drift and stranding in the Flathead and Kootenai Rivers, Montana, USA. Hydrobiologia, 134: 171182.

Pimm, S. L. 1984. The complexity and stability of ecosystems. Nature, 307: 321-326.

Poff, N. L. 1996. A hydrogeography of unregulated streams in the United States and an examination of scale-dependence in some hydrological descriptors. Freshwater Biology, 36: 101-121.

Poff, N. L., J. D. Allan, M. B. Bain, J. R. Karr, K. L. Prestegaard, B. D. Richter, R. E. Sparks \& J. C. Stromberg. 1997. The Natural Flow Regime. A paradigm for river conservation and restoration. BioScience, 47: 769-784.
Pompeu, P. S. \& H. P. Godinho. 2006. Effects of extended absence of flooding on the fish assemblages of three floodplain lagoons in the middle São Francisco River, Brazil. Neotropical Ichthyology, 4: 427-433.

Pompeu, P. S., L. S. dos Reis, C. V. Gandini, R. C. R. de Souza \& J. M. Del Favero. 2009. The ichthyofauna of upper rio Capivari: defining conservation strategies based on the composition and distribution of fish species. Neotropical Ichthyology, 7: 659666.

Postel, S. \& B. Richter. 2003. Rivers for life: Managing water for people and nature. Washington, Island Press.

Prejs, A. \& K. Prejs. 1987. Feeding of tropical freshwater fishes: seasonality in resource availability and resource use. Oecologia, 71: 397-404.

Suzuki, F. M., L. P. Zambaldi, P. S. Pompeu. 2008. Mapping the critical habitats for migratory species of the upper Grande River region, Minas Gerais state, Brazil. Applied Ecology and Environmental Research, 11: 645-659.

Tupinambás, T. H., R. M. V. Cortes, S. G. Varandas, S. J. Hughes, J. S. França \& M. Callisto. 2013. Taxonomy, metrics or traits? Assessing macroinvertebrate community responses to daily flow peaking in a highly regulated Brazilian river system. Ecohydrology, 1-15.

Tupinambás, T. H. 2013. Efeitos de alterações de vazão em comunidades bentônicas e interações tróficas com a ictiofauna bentófaga. Unpublished Ph.D. Dissertation, Universidade Federal de Minas Gerais, Belo Horizonte, 125p.

Welcomme, R. L. 1985. River fisheries. FAO Fisheries Technichal Paper, 262: 330.

Submitted September 7, 2013 Accepted April 29, 2014 by Norma S. Hahn 